\title{
Spatial Variability of the 'Airbnb Effect': A Spatially Explicit Analysis of Airbnb's impact on Housing Prices in Sydney
}

\author{
William Thackway, Matthew Ng, Chyi-Lin Lee, Vivien Shi, Christopher Pettit
}

December 2021

\begin{abstract}
Over the last decade, the emergence and significant growth of home sharing platforms such as Airbnb has coincided with rising housing unaffordability in many global cities. It is in this context that we look to empirically assess the impact of Airbnb on housing prices in Sydney - one of the least affordable cities in the world. Employing a hedonic property valuation model, our results indicate that Airbnb's overall effect is positive. A $1 \%$ increase in Airbnb density is associated with approximately a $2 \%$ increase in property sales price. However, recognising that Airbnb's effect is geographically uneven and given the fragmented nature of Sydney's housing market, we also employ a GWR to account for the spatial variation in Airbnb activity. The findings confirm that Airbnb's influence on housing prices is varied across the city. Sydney's northern beaches and parts of western Sydney experience a statistically significant value uplift attributable to Airbnb activity. However, traditional tourist locations focused around Sydney's CBD and the eastern suburbs experience insignificant or negative property price impacts. The results highlight the need for policymakers to consider local Airbnb and housing market contexts when deciding the appropriate level and design of Airbnb regulation.
\end{abstract}

Keywords: housing prices, housing affordability, Airbnb, sharing economy, spatial modelling, Sydney

\section{Introduction}

The rise of the sharing economy brought about by digital disruption is having a profound impact on how our cities function. Among the largest of these sharing economy companies is Airbnb, a homesharing platform that was founded in 2008 and serves as an exemplar of the sharing economy (Zervas et al., 2017). The enabling of the sharing economy through the internet, coupled with the rising demand globally for urban tourism (up 45\% in the 132 most popular cities from 2009 to 2015), has provided the ideal market setting for Airbnb to cater to people's growing desire to travel cheaply and authentically (Guttentag et al., 2017). While earlier Airbnb studies investigated its interplay with traditional hotel accommodation (Guttentag et al., 2017), more recent studies have turned their attention to its impact on the housing market.

While initially hailed as an avenue to increase accessible, affordable housing, evidence from several global cities suggest that the informal housing options provided through Airbnb have instead exacerbated several urban housing issues. In London, the emergence of short-term rentals has presented an attractive option for offshore investors and private companies to capitalise on London's exorbitant housing costs and ample tourist demand, contributing additional pressure to London's housing market (Shabrina et al., 2021). Similarly, in New York, there is evidence that Airbnb has accelerated the process of gentrification and appears to be creating a new form of rent gap (Wachsmuth \& Weisler, 2018). 
Finally, in Sydney, Gurran et al. (2020) found that short term rental (STR) platforms such as Airbnb typically rented to the more affluent sector of the rental market and provided limited affordable alternatives to formal rental stock. Hence, there is increasingly criticism over the ramifications of Airbnb's presence in the housing market, given housing affordability is already a critical concern in many urban areas where tourism thrives (Lee, 2016).

Moreover, the temporary standstill of global travel during the COVID-19 pandemic has served to highlight the disruptive impact of Airbnb on housing markets. In Sydney, Thackway \& Pettit (2021) evidenced a clear relationship between declining Airbnb activity and reductions in rental prices, with rental prices falling by up to $7.1 \%$ in the most active neighbourhoods. Similarly, Buckle \& Phibbs (2021) attributed a $1.8 \%$ increase in vacancy rates and a $6 \%$ fall in median rents in Hobart City to a decline in Airbnb stock during the first COVID lockdown. By demonstrating the affordability improvements of reduced Airbnb activity, these studies have once again brought the inflationary effect of Airbnb under scrutiny. Furthermore, the high degree of variability in housing market responses to the pandemic within cities (Thackway \& Pettit, 2021) raises the question of how Airbnb's impact varies across different housing submarkets.

This study, therefore, aims to contribute to the Airbnb housing market debate by providing empirical evidence on the overall and variable impact of Airbnb on property prices. Firstly, this study contributes to the limited studies of disruptive technology on housing markets, particularly Greater Sydney. Previous Sydney-based studies have investigated how Airbnb affects long-term leases and rental prices (Thackway \& Pettit, 2021; Gurran \& Phibbs, 2017). This paper seeks to extend the discourse of these studies by examining how Airbnb activities affects housing prices. Using detailed property sales data and unique AirDNA Airbnb data, the impact of Airbnb on housing prices is gauged for the first time at an individual property level. Unlike previous studies examining Airbnb's effect on property prices at an aggregate level, we evaluate Airbnb's effect in the context of residential property valuation. A micro level study is of particular interest to policy makers, homeowners and property developers, and contributes to the ongoing debate of whether Airbnb should be further regulated.

Secondly, our study assesses the Airbnb effect in different submarkets for the first time. Considering the geographical unevenness of Airbnb's activity in Sydney (Crommelin et al., 2018a) as well as the spatial fragmentation of Sydney's housing market (Randolph \& Tice, 2013), a spatially invariant model will overlook the spatial nuances of Airbnb's influence on the housing market. By using disaggregated data (i.e., individual properties) instead of aggregated housing indices, we employ a Geographically Weighted Regression (GWR) to capture the spatial variation of Airbnb's influence more effectively. This offers a fuller understanding of residents' preference for this new disruptive technology in different submarkets and sheds light on the importance of considering submarket dynamics in policy analyses. Crucially, these findings highlight the need for policymakers to consider local tourist and housing market drivers when designing Airbnb regulations. Our findings also contribute to the ongoing debate on the importance of submarket analyses for housing and Airbnb activity.

\subsection{Why Sydney as a Case Study}

Sydney presents a case study of a very active Airbnb presence in an extremely inflated housing market, with distinct housing submarkets that provide the potential for a variable Airbnb effect. Sydney is a global city and a popular tourist destination, providing a clear rationale for Airbnb activities, with 12.7 million domestic and 4.1 million international visitors in 2019. A heat map of Airbnb density within Sydney postcodes, shown in Figure 1, illustrates Airbnb hotspots are clustered around the City $\mathrm{CBD}$, and the Eastern (Bondi) and Northern (Manly) Beaches.

Since its introduction in 2009, Airbnb activity in the greater Sydney region has grown at an exponential pace to over 23,000 active listings at the start of 2021, making it the fourth largest Airbnb market worldwide (Boros et al., 2020). Simultaneously, rental and sale prices in Sydney have outpaced 
average earnings for over two decades, culminating in house prices more than doubling in real terms (Daley \& Coates, 2018). Housing affordability in Sydney is the third worst of any city globally, with a median multiple (median house price/median annual income) of over 11 (Cox \& Pavletich, 2020). The concurrence of Airbnb and housing price growth raises the question of whether and to what extent Airbnb has contributed to Sydney's housing affordability crisis.

Figure 1. Distribution of Airbnb activity throughout Sydney

(a) Sydney

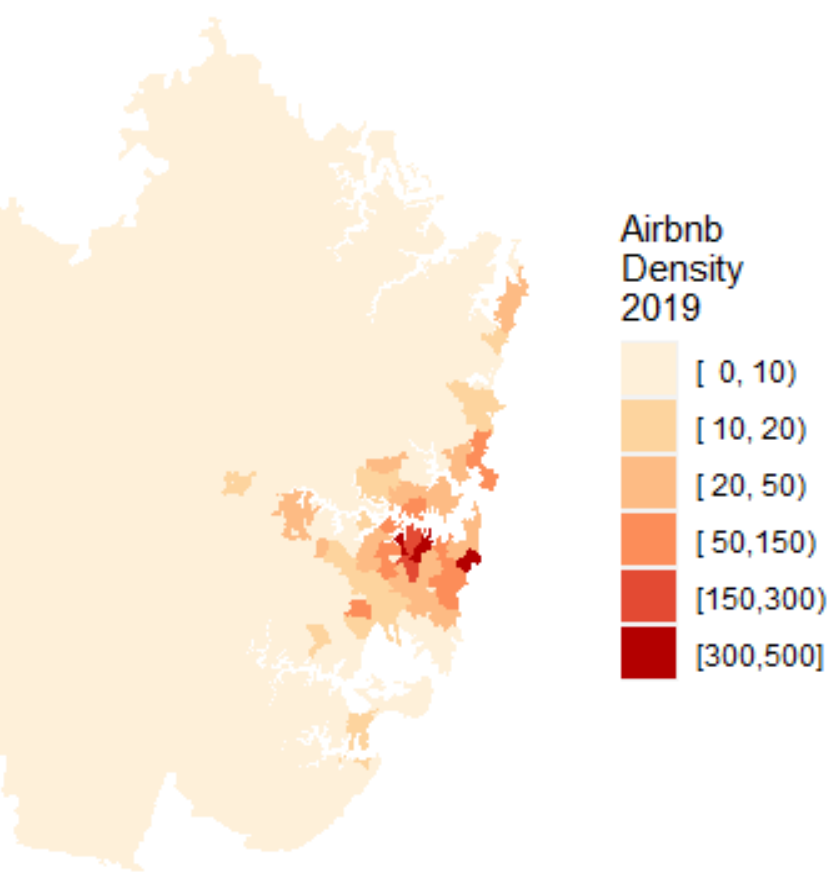

(b) Zoom into inner Sydney

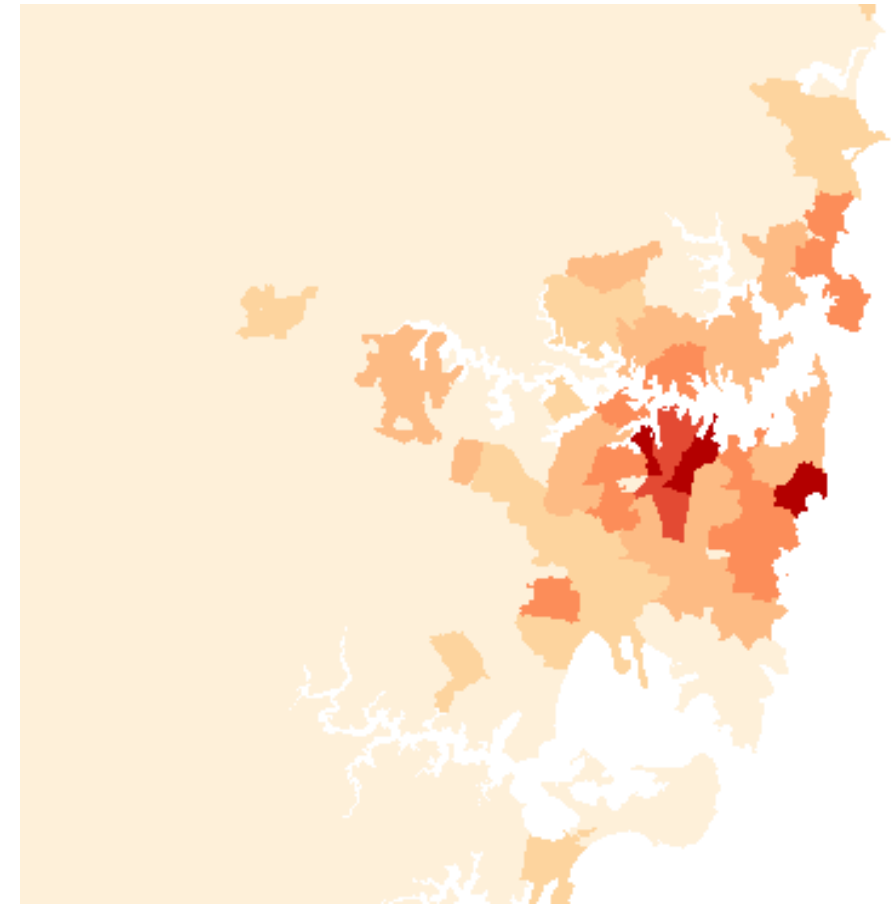

However, policymakers have broadly shown little attention to the potential ramifications of Airbnb's emergence into the Sydney housing market. Policy responses to Airbnb in Sydney were initially slow and seen as inadequate at a local government level (Gurran \& Phibbs, 2017), yet, in recent years, there has been an attempt to restrict its impact on local residents and the housing market. In June 2018, the NSW Government brought in the Fair-Trading Amendment (Short-Term Rental Accommodation) Act, which capped the number of days for whole home rentals, where the host is not present, to 180 days a year in the Greater Sydney area. This followed the lead of other global cities such as London, who implemented a 90 day per year Airbnb cap in 2015 (Shabrina et al., 2021), and Paris, who restrict Airbnb's to 4 months a year (Nieuwland \& Van Melik, 2020). While these moderate restrictions acknowledge the disruptive impact of Airbnb on Sydney's housing market, they are nonetheless towards the least imposing of Airbnb restrictions worldwide (Nieuwland \& Van Melik, 2020). While political unwillingness may contribute to the slowness and leniency of Sydney's policy response towards Airbnb, a lack of quality empirical evidence on Airbnb's housing market impact reduces the pressure on government and planning agencies to intervene (Nieuwland \& Van Melik, 2020). Indeed, Gurran \& Phibbs (2017) stress the importance of targeted research for individual cities to tailor Airbnb regulation strategies, given its impact can vary significantly between cities.

Several researchers have examined the link between Airbnb activity and effects on the housing market. Gurran \& Phibbs (2017) evidenced a home sharing premium in Sydney, illustrating that median monthly rent for frequently available Airbnb listings exceeded that of long-term rentals by $\$ 600$. Furthermore, Crommelin et al. (2018b) demonstrated that the increase of listings in Sydney's most Airbnb dense neighbourhoods coincided with reductions in rental bond lodgement numbers. More recently, Thackway \& Pettit (2021) explored how reductions in Airbnb listings in high activity Airbnb neighbourhoods during the COVID-19 pandemic coincided with increased rental supply and reduced prices. These studies in aggregate present a clear correlation between increased Airbnb activity and 
reduced supply of units in the long-term market. Yet, none of these studies have explored the impact of Airbnb on the Sydney property market from the perspective of residential property valuation. The methodologies in previous Sydney-based Airbnb studies have been rudimentary, using data analysis and comparison of spatial patterns. This study seeks to extend the discourse on Airbnb's impact in Sydney by studying the effect of Airbnb on housing prices for the first time through robust hedonic analysis.

Furthermore, it is noted in research of Airbnb in Sydney that the spread of Airbnb is geographically uneven (Crommelin et al., 2018a). The existence of housing submarkets in Sydney is also well documented, with a distinct divide between the high-end submarket in waterfront and innercity areas and the low-end submarket in the middle and outer suburbs (Bangura \& Lee, 2020a). Indeed, Randolph \& Tice (2013) argue that the Sydney housing market operates in a spatially fragmented manner due to the spatial discontinuity of its housing submarkets. Importantly, Bangura \& Lee (2020a, 2020b) have shown that high and low-end housing submarkets do not follow the same pricing mechanism. Yang et al. (2019) and Wen et al. (2019) also found that high-end and low-end home buyers have different preferences. Therefore, it is reasonable to expect that among the different housing submarkets present in Sydney, housing prices will exhibit varying responses to the entrance of Airbnb. Yet, despite the acknowledgement of geographical unevenness of Airbnb activity in Sydney and fragmentation of Sydney's housing market, there has been no attempt to account for these spatial nuances through modelling techniques. This study therefore employs a spatial dimension using a GWR to account for the spatial variation of Airbnb's impact across Sydney.

\section{Literature Review}

\subsection{Airbnb Housing Market Studies}

Despite the strong anecdotal evidence and theoretical discussion of Airbnb's impact in local policy debates, there is a limited pool of empirical research into its impact on the housing market. While several initial studies use data insights to explore linkages between Airbnb and the housing market (Gurran \& Phibbs, 2017; Crommelin et al., 2018a), more recently, Airbnb housing analysis has shifted towards empirical studies to investigate the impact on residential property value as evidenced through sales transactions. Appendix A presents a summary of the empirical studies analysing the impact of Airbnb on the housing market that this paper identified.

Horn \& Merante (2017) performed one of the earliest hedonic regression analyses, using a simple linear regression with Airbnb Density as the explanatory variable to model rental prices. The simple hedonic approach assumes that the Airbnb Density measure is exogenous - that is there is no reverse causation and Airbnb Density is uncorrelated with the error term. However, since the hedonic equation is a reduced form model, it is unwise to make this assumption. Barron et al. (2020) addressed this concern by substituting the Airbnb Density measure with an Instrumental Variable (IV) that can be assumed exogenous. Barron et al. (2020) was the first study identified to address Airbnb's influence on property prices. Garcia-Lopez (2020) and Franco et al. (2021) applied similar methodologies to Barcelona and Lisbon/Porto respectively, however both proposed new methods to measure the 'share' component of the IV.

These three studies comprehensively explore the linkage between Airbnb and property prices, sequentially adding control variables as well as employing a wide range of robustness checks. The validity of the IV is discussed at length and the instability concerns of the explanatory variable in the simple hedonic model have been addressed. However, in all three studies, the models are applied at an aggregate scale to predict the price index of each municipality, instead of through the lens of property valuation applied at an individual property level. Resultingly, many traditional property valuation variables used to describe property and neighbourhood characteristics are neglected, such as proximity to amenities, mobility, and individual property attributes. Indeed, aggregate property models generally 
contain less detail than traditional hedonic models that predict individual property rent or price (Belniak \& Wieczorek, 2017). This study therefore contributes new empirical findings by applying a hedonic approach at the individual property level to quantify the impact of Airbnb on housing prices from a property valuation perspective.

Furthermore, despite discussion of the geographic dispersion of the 'Airbnb effect' (Franco et al., 2021; Adamiak et al., 2019), there is no attempt in the methodologies used to account for the spatial nuances of Airbnb's impact, with all three studies employing spatially invariant approaches. The linear regression approach employed assumes changes across space to be universal. However, when there is spatial non-stationarity present in the data, spatial variations in different regions will be lost due to global coefficient estimates for each variable (Brunsdon et al., 1996). The Geographically Weighted Regression (GWR) provides a method to incorporate spatial heterogeneity in modelling, by fitting a linear regression for each individual point locally to allow for spatial variation in local parameter estimates (Fotheringham et al., 2003; Shabrina et al., 2020). GWR has been used in housing research to analyse market segmentation (Manganelli et al., 2014) and model spatial variability in rent (Zhang et al., 2019). It has also been applied to Airbnb to model Airbnb price determinants (Suarez-Vega et al., 2020) and examine its spatial relationship to core elements of urban tourism such as hotels, restaurants, and transport (Shabrina et al., 2020). However, the use of GWR to examine the impact of Airbnb on property prices is absent from the literature. Therefore, this study seeks to account for the spatial heterogeneity of the Airbnb effect identified by implementing a spatially explicit model for the first time to understand how Airbnb's impact varies across Sydney.

\subsection{Conceptual Framework}

In this paper we do not seek to present a new theoretical framework, rather to couch our empirical findings within the conceptual dimensions developed by other studies of how Airbnb might interact with the property market in the broader context of the city. Furthermore, we acknowledge that there are many variables that have a profound impact on housing prices, as well as place-specific complexities derived from different macroeconomic and regulatory environments (Tu et al., 2017). However, we believe it is valuable to study the specific impacts of Airbnb, whose disruption of the housing market is unique and has emerged only over the last decade. How Airbnb might influence the housing market has been discussed through both demand and supply mechanisms.

Firstly, researchers have argued that the additional revenue generating capacity enabled through Airbnb creates excess demand for units in the long-term market in areas with high Airbnb (Horn \& Merante, 2017; Franco et al., 2021). On the other hand, negative externalities such as noise, congestion, safety concerns, and access to local amenities may decrease demand for high-activity Airbnb areas (Cocola-Grant, 2016).

On the supply side, it is argued that Airbnb blurs the segmentation between the long-term and short-term rental markets (Barron et al., 2020). Evidence suggests that Airbnb has daily rates far exceeding those of long-term rental accommodation, implying a 'home sharing premium'. The average daily rate of Airbnb listings compared to long-term rental units has been found to range from 2.5 times higher in Boston to 6.5 times higher in Barcelona, with magnitudes varying dependent on the base affordability of a city's rental stock (Horn \& Merante, 2017; Garcia-Lopez et al., 2020). This might be expected, given the short-term nature of the tenancies may mean longer periods during which properties are vacant (Garcia-Lopez et al. 2020). The existence of this premium provides landlords, who are traditionally segmented to supplying the long-term market, with an opportunity to increase their revenue earning potential by entering the short-term market. Theoretically, if landlords can gain more revenue and hence utility by converting long-term units to short-term rentals; then, as a utility maximising agent they will do so (Muller, 2014). Therefore, it is expected that some supply of units in the long-term market supplied by traditional landlords will be lost to short-term rentals. This is supported by evidence in New York and Toronto of landlords displacing tenants, either directly or through exclusionary measures to introduce held properties into the short-term market (Wachsmuth \& Weisler, 2018; Grisdale, 2019). Furthermore, it is not expected that traditional suppliers of the short-term market (hotels and bed and breakfasts) will enter the long-term market, due to regulatory and development 
costs (Barron et al., 2020). Hence, the total supply of units in the long-term market is expected to decrease. Empirically, Horn \& Merante (2017) found in Boston that on average 4.5 long-term rental units per census tract are lost weekly to Airbnb, while Saaman (2015) found that home-sharing platforms take 11 units off the local rental market each day in the Los Angeles locality.

DiPasquale-Wheaton's (1992) Four-Quadrant Model, the most popular macroeconomic model of the housing market, can be used to discuss the impact of reduced rental supply on housing prices. DiPasquale \& Wheaton (1992) assert that rental price is a fundamental variable to explain asset price/housing price. Importantly, a shift in rental supply is inversely related to rental prices. As such, the notion of Airbnb activity reducing the supply of long-term housing has resulted in a higher level of housing rent, as highlighted by Horn \& Merante (2017). If there is an acute impact on rents, it is reasonable to expect that this should have an impact on housing prices, as rent is a key fundamental variable to explain housing prices (Bangura \& Lee, 2020a).

Therefore, this paper makes several hypotheses based on the conceptual framework discussed:

1. It is expected that Airbnb activities lead to a higher overall level of housing price.

2. The impact on housing prices is expected to be greater in high activity Airbnb areas where more long-term rentals are expected to be lost to Airbnb.

3. It must be noted however, that negative externalities associated with Airbnb will also increase in tourist areas. Hence, the competing pressures of reduced supply and negative demand externalities may manifest varied housing market impacts across different housing submarkets.

\section{Methods and Materials}

\subsection{Data}

The Airbnb data was obtained from AirDNA, containing information on the price, location, host, and reservation history of all listings within Australia since 2009. Properties listed as Airbnb were filtered monthly between 2018 and 2020 using the 'Date Created' and 'Date Last Scraped' fields. Active listings were selected by filtering out listings with no revenue in the previous year. Each listing was aggregated to the postcode level by geolocating each point within the Postcode boundaries obtained through the Australian Bureau of Statistics' 2016 update of Australian Statistical Area boundaries. See Table 1 for sources of the data inputs for the hedonic and GWR modelling.

Property sales data was provided by the Australian Property Monitors (APM) company, which is comprised of residential sales data monthly. From the geolocation of each property, the proximity of the property to neighbourhood amenities and points of interest was calculated based on Euclidian distance analysis. The location of these points of interest were obtained through data from Open Street Map.

Finally, for the IV Specification, monthly Google Trends data was scraped from the publicly available website Google Trends using a refined search of the word 'Airbnb'.

The selected model variables were assessed with a correlation analysis and a Variance Inflation test. The results suggest no evidence of collinearity among these variables (See Appendix B). 
Table 1. Summary of data sources, use and key variables

\begin{tabular}{|c|c|c|c|c|}
\hline Name & $\begin{array}{l}\text { AirDNA } \\
\text { Australia }\end{array}$ & $\begin{array}{l}\text { APM } \\
\text { Sydney }\end{array}$ & $\begin{array}{l}\text { OSM } \\
\text { NSW }\end{array}$ & $\begin{array}{l}\text { Ggl Trends } \\
\text { NSW }\end{array}$ \\
\hline Source & AirDNA & $\begin{array}{l}\text { Australian } \\
\text { Property } \\
\text { Monitors }\end{array}$ & Open Street Map & Google Trends \\
\hline Use & Airbnb Data & $\begin{array}{l}\text { Residential sales } \\
\text { data }\end{array}$ & $\begin{array}{l}\text { Location of } \\
\text { Amenities \& } \\
\text { Points of Interest }\end{array}$ & $\begin{array}{l}\text { Measuring } \\
\text { Google Trends } \\
\text { of the word } \\
\text { 'Airbnb' }\end{array}$ \\
\hline $\begin{array}{l}\text { Key } \\
\text { Variables }\end{array}$ & $\begin{array}{l}\text { Long/Lat of } \\
\text { Listing, Date } \\
\text { created/last } \\
\text { scraped, Price, } \\
\text { HostID, Room } \\
\text { type, No. } \\
\text { Reservations }\end{array}$ & $\begin{array}{l}\text { Long/Lat of } \\
\text { Property, Sale } \\
\text { price, Sale date, } \\
\text { Bedrooms, } \\
\text { Bathrooms, } \\
\text { Pool, Garage, } \\
\text { House }\end{array}$ & $\begin{array}{l}\text { Location of } \\
\text { Beaches, } \\
\text { Hospitals, } \\
\text { Universities, } \\
\text { Schools, } \\
\text { Railway/Bus } \\
\text { stops, Parks }\end{array}$ & $\begin{array}{l}\text { Monthly } \\
\text { Google Trends } \\
\text { score }\end{array}$ \\
\hline
\end{tabular}

\subsection{Baseline OLS Specification}

The Ordinary Least Squares (OLS) regression model was constructed to evaluate Airbnb's overall effect on housing prices in Sydney. The model was performed at the property level with monthly data updates throughout the 2019 calendar year. The aggregation for the Explanatory Variable, Airbnb Density, was at the postcode level; the smallest spatial aggregation level possible for the data.

The model was as follows:

$$
\begin{gathered}
Y_{i t c}=\alpha+\beta_{1} \log \left({\text { AbbDensity })_{c t}+}_{2} \beta_{2} \text { Bedroom }_{i c t}+\beta_{3} \text { Bathroom }_{i c t}+\beta_{4} \text { Parking }_{i c t}+\beta_{5} \text { House }_{\text {ict }}\right. \\
+\beta_{6} \text { Covariates }_{i c t}+\gamma \text { Postcode }_{c}+\text { SMonth }_{t}+\varepsilon_{i c t},
\end{gathered}
$$

where $Y_{i t c}$ is the natural $\log$ of sale price for a property $\mathrm{i}$, in postcode c (postcode area) in period $\mathrm{t}$ (where periods are given in months). AbbDensity $y_{c t}$, representing the density of active Airbnb listings within a postcode, is calculated for a postcode $c$ in time period $t$ by dividing the total number of active Airbnb listings in that postcode by the area in square $\mathrm{km}$ of the postcode. The Airbnb density variable is heavy tailed; therefore, we take the log transformation of this variable to induce normality.

Apart from Airbnb listings, fifteen property valuation variables were selected to capture individual property characteristics, neighbourhood amenities, and the property's location with respect to major landmarks (e.g., beach, CBD). The full list of variables can be seen in Table 3. Comparable hedonic property pricing models in Sydney have applied a similar range of property, amenity and location variables (Lieske et al., 2019; Rayaprolu \& Levinson, 2019). Bedroom ict $_{\text {and }}$ Bathroom ict $_{\text {ict }}$ denote the number of bedrooms and bathrooms, Parking ict is a flag for parking and Covariates ict denotes a vector of time-invariant amenities within the property's proximity. Notably, distance to coastline and city centre, both identified as traditional hotspots for Airbnb activity in Sydney, have been included to control for Airbnb's spatial tendency towards high-price areas. This may raise concerns over collinearity; however, the Variance Inflation Test (Appendix B) shows no signs of collinearity

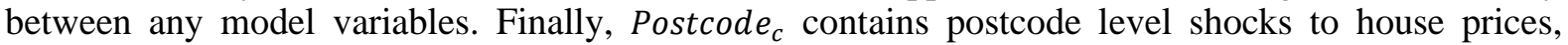
$M o n t h_{t}$ denotes time-varying shocks to house prices, and $\varepsilon_{i c t}$ contains any unobserved postcode level or time-varying factors affecting house prices. 


\subsection{Instrumental Variable Specification}

As aforementioned, a concern with the baseline OLS regression is the potential correlation of the unobserved postcode level or time-varying factors contained in the error term $\varepsilon_{i c t}$ with the explanatory

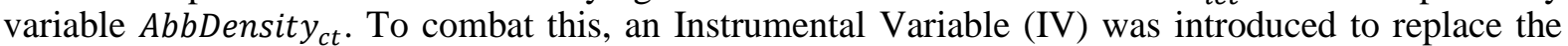
explanatory variable, following the two-stage-least-squares (TSLS) method developed by Barron et al. (2020). This IV introduces a 'shift-share' variable, whereby the 'share' component predicts where Airbnb activity will occur, and the 'shift' component predicts when Airbnb activity will occur. The share component of the IV specification was a time-invariant measure of "Touristy-ness" for each postcode, while the shift component was a measure of "Airbnb Awareness" for each month. This specification assumes that each postcode has a base level of "touristy-ness" that remains static, and that Airbnb activity in each postcode will only change with fluctuations in general societal awareness of Airbnb as an option for travellers and landlords.

The approach of Franco et al. (2021) was followed to construct the share component of the IV, by predicting the "touristy-ness" of an area through Airbnb density at a fixed point in time immediately prior to the study period; AbbDensity $y_{c, 2018}$ Dec. The time-varying measure of monthly Airbnb Awareness was captured through Google Trends of the word "Airbnb" at an aggregate level (NSW), representing the appropriateness of use of Airbnb for tourists and landlords; GglTrends $s_{t}$. The new Airbnb Density measure was created by multiplying the 'shift' and 'share' components of the IV as follows:

$$
\text { AbbDensity_I }_{c t}=\text { AbbDensity }_{c, 2018 \text { Dec }} * \text { GglTrends } s_{t}
$$

The IV procedure was carried out using a two-stage-least-squares (TSLS) regression, as outlined in Barron et al. (2020). Thereafter, the IV can be assumed exogenous. For further discussion of the motivation and execution of this IV procedure, see Barron et al. (2020).

\section{$3.4 G W R$}

The GWR model was employed to assess the spatial variation of Airbnb's housing market impact. The model was constructed using Equation (1) with the same property sales and Airbnb data as inputs. The Postcode control variable was omitted, as spatial variation in housing prices is accounted for through the spatially explicit method of the GWR.

The core specifications in conducting a GWR are the choice of optimum bandwidth and kernels (Shabrina et al. 2020). The bandwidth determines the radius around each individual point within which observations are considered in that point's local regression. The choice of optimum bandwidth is informed by the choice of kernel. For a visual interpretation of the kernel choice, see Appendix C.

The fixed spatial kernel uses a fixed distance parameter and therefore assumes a uniform distribution of spatial data. However, when there is variable spatial density in the data, a fixed kernel will result in areas with sparse data having insufficient regression points (Fotheringham et al. 2003). In this case, an adaptive kernel using k-nearest neighbours is better, as the kernel will adjust according to the density of data for each observation. In Sydney's case, where urban sprawl has resulted in high variability of population density (Garden \& Jalaludin, 2009), an adaptive kernel was deemed more appropriate.

The weighting function of the kernels must also be considered (Fotheringham et al., 2003). The gaussian weighting function gradually decreases the weight assigned to all points outwards from the centre of the kernel, with no weight ever equalling zero. The bisquare function on the other hand sets the weight for all points outside of the optimum bandwidth to zero. The gaussian kernel was ultimately selected, as it optimised the goodness of fit of the model. Finally, after specifying these elements of the kernel, the optimum bandwidth was calculated by minimising the corrected Akaike Information Criterion (AICc). 


\section{Methodology}

\subsection{Hedonic Modelling Results}

Table 2 reports the results of the OLS and IV model predictions of the Airbnb Density coefficient. Given equation (1) follows a log-to-log transformation of the dependent and explanatory variable, the baseline OLS model's coefficient of 0.0844 (column (2)) implies a 1\% increase in Airbnb density is associated with an $8.44 \%$ increase in sales price. Given Crommelin et al. (2018b) noted that Airbnb activities resulted in a reduction of long-term rental supply, it is reasonable to expect an upward movement of rent and housing prices. This is also consistent with the assertion of DiPasqualeWheaton's (1992) Four-Quadrant model in which a reduction of rental housing supply is expected to lead to a higher level of rent and price, ceteris paribus.

Table 2. Hedonic Modelling Results

\begin{tabular}{|c|c|c|c|c|}
\hline & (1) & (2) & (3) & (4) \\
\hline Model & Baseline & Baseline OLS & Control OLS & IV \\
\hline Dep. Variable & \multicolumn{4}{|c|}{$\log$ (sales) } \\
\hline Airbnb Density & & $0.0844^{* * *}$ & $0.0301^{* * *}$ & $0.0201^{* * *}$ \\
\hline (Standard Error) & & $(0.0020)$ & $(0.0019)$ & $(0.0024)$ \\
\hline Observations & 36,264 & 36,264 & 36,264 & 36,264 \\
\hline (Intercept) & 12.749 & 12.700 & 12.94 & 13 \\
\hline Bedrooms & 0.085 & 0.106 & 0.113 & 0.112 \\
\hline Baths & 0.112 & 0.096 & 0.079 & 0.080 \\
\hline Parking & 0.036 & 0.046 & 0.040 & 0.040 \\
\hline Dist. City Centre & -0.000 & -0.000 & -0.000 & -0.000 \\
\hline Dist. Coast & -0.000 & -0.000 & -0.000 & -0.000 \\
\hline Dist. B1_4 & -0.000 & -0.000 & -0.000 & -0.000 \\
\hline Dist. Swim Place & -0.000 & -0.000 & -0.000 & -0.000 \\
\hline Dist. In123 & -0.000 & -0.000 & -0.000 & -0.000 \\
\hline Rail20_400 & 0.144 & 0.082 & 0.030 & 0.030 \\
\hline Rail24_800 & 0.126 & 0.077 & 0.241 & 0.025 \\
\hline Rail28_1600 & 0.073 & 0.044 & 0.004 & 0.037 \\
\hline CrmRate & -0.227 & -0.200 & -0.015 & -0.010 \\
\hline MedFamInc & 0.000 & 0.000 & 0.000 & 0.000 \\
\hline Main100 & 0.006 & -0.016 & -0.023 & -0.022 \\
\hline RailLi100 & -0.065 & -0.047 & -0.061 & -0.064 \\
\hline Adjusted $\mathrm{R}^{2}$ & 0.746 & 0.796 & 0.868 & 0.871 \\
\hline RSS & 2593.372 & 2028.709 & 1312.713 & 1288.169 \\
\hline AICc & 7287.198 & -1615.774 & -17289.324 & -17973.784 \\
\hline
\end{tabular}

Significance levels: ${ }^{* * *} P<0.01,{ }^{* *} P<0.05,{ }^{*} p<0.1$

Notes: Robust Standard Errors used. GOF statistics evaluated are: Adjusted R ${ }^{2}$ (adjusted coefficient of determination), RSS (Residual Sum of Squares), AICc (Corrected Akaike Information Criterion)

Introducing controls for time-varying and neighbourhood level shocks through the Month and Postcode variables significantly reduces the estimated magnitude of the Airbnb density coefficient (column (3)). This is to be expected, given that any observable spatial or temporal shocks to housing 
prices that may previously have been attributed to the Airbnb variable are now controlled for. The OLS model with month-fixed and postcode-level controls associates a $3.01 \%$ increase in property sales prices with a $1 \%$ increase in Airbnb density.

Upon implementing the TSLS regression with an IV specification, a positive and statistically significant coefficient for Airbnb density is evident. This confirms the robustness of our baseline results in which Airbnb activities do have a positive impact on housing prices. Specifically, the IV model implies a $1 \%$ increase in Airbnb density is associated with a $2.01 \%$ (column (4)) increase in house prices. The magnitude of Airbnb density in Model (3) declines slightly compared with Model (2). This is in line with expectations, as the purpose of the IV specification was to remove any correlation of the instrumental variable with the error term and capture the effects of Airbnb more accurately. Barron et al. (2020) provide detailed discussion of the validity of the IV term constructed through the 'shift-share' approach, concluding that it can be assumed exogenous from time-varying, municipality level shocks. The exogeneity of the IV term with unobserved shocks contained in the error term is expected to provide the most accurate estimate of the Airbnb density variable. Therefore, the IV Airbnb density coefficient is the preferred measure of Airbnb's impact on housing prices in Sydney.

For the average postcode in terms of Airbnb activity (3.074), the IV Airbnb density coefficient implies a house price increase of $2.26 \%$, lower than the result of $3.7 \%$ in Barcelona (Garcia-Lopez et al., 2020). However, with 50\% more tourists annually in a city with roughly a third of Sydney's population, it must be noted that Barcelona's tourist market is far more substantial than the Sydney market. Similarly, our estimate of a $2.01 \%$ increase in housing prices associated with a $1 \%$ increase in Airbnb density is lower than the estimate of 3.5\% in Lisbon and Porto (Franco et al., 2021), however there is a similar disparity in Sydney and Portugal's tourist markets. It must also be observed that these figures are not directly comparable, given the different spatial granularity used in other studies performed at an aggregate level. Nonetheless, our results are roughly aligned when considering the relative tourist markets of comparable studies.

In each stage of hedonic modelling the explanatory variable is statistically significant and presents a clear associational impact of Airbnb activity increasing property prices. Through the use of individual property sales data, we are able to evaluate the magnitude of Airbnb's impact for the first time in the context of residential property pricing. In general, this does show that Airbnb activity leads to a higher level of housing prices. However, the application of an OLS model to estimate Airbnb's effect on the housing market ignores both the spatial variation of Airbnb activity and housing submarkets within Sydney. We therefore turn to a GWR to capture the spatial nuances of Airbnb's relationship with the Sydney housing market.

\subsection{GWR Results}

Table 3(a) compares the goodness of fit (GOF) of the spatially explicit model against the global models, and by all metrics the GWR outperforms the OLS models. The adjusted $\mathrm{R}^{2}$, which measures the proportion of total variation captured by the model, is 0.911 for the GWR compared to 0.871 for the best performing OLS model. Furthermore, the GWR reduces the residual sum of squares of the IV model by a third from 1288.169 to 886.834 , indicating that there is less unexplained variance in the spatially explicit model. Finally, the corrected Akaike Information Loss (AICc) reduces from $17,973.784$ with the IV model to $-26,824.740$ for the GWR model, demonstrating that the GWR model minimises information loss in the model.

Table 3(b) summarises the distribution of coefficient parameter estimates for the GWR. It must be noted that GWR is foremost a descriptive spatial tool rather than a detailed method for causal inference (Shabrina et al., 2020). Therefore, the magnitudes of coefficient estimates are not the primary concern of the GWR analysis, rather the variation of the directional association (i.e., positive/negative) of the Airbnb density term and property prices. The median Airbnb Density coefficient of 0.0127 
corroborates the hedonic modelling results that Airbnb has the predominant impact of increasing property prices. However, the 1 st quantile estimate of -0.0432 implies that for a significant portion of Sydney properties, Airbnb has a negative influence on prices. Therefore, while Airbnb's overall effect on the property market is positive, the GWR results demonstrate that this impact is not homogenous, and in some cases the negative externalities produced by Airbnb may also reduce property prices.

Table 3. GWR Model Results

a) Comparison of Goodness of Fit of OLS and GWR models

\begin{tabular}{l|ccc}
\hline Model & Adj R & RSS & AICc \\
\hline Baseline OLS & 0.796 & 2028.709 & -1615.774 \\
Control OLS & 0.868 & 1312.713 & -17289.324 \\
IV & 0.871 & 1288.169 & -17973.784 \\
GWR & 0.911 & 886.834 & -26824.737 \\
\hline \hline
\end{tabular}

b) Summary of GWR coefficient estimates

\begin{tabular}{l|ccccc}
\hline & $(1)$ & $(2)$ & $(3)$ & $(4)$ & $(5)$ \\
\hline & Min & Q1 & Median & Q3 & Max \\
\hline Observations & 36,264 & 36,264 & 36,264 & 36,264 & 36,264 \\
& & & & & \\
\hline Airbnb Density & -0.1217 & -0.0432 & 0.0127 & 0.031 & 0.1456 \\
\hline & & & & & \\
(Intercept) & 10.707 & 12.635 & 13.278 & 13.728 & 19.971 \\
Bedrooms & 0.003 & 0.082 & 0.102 & 0.132 & 0.213 \\
Baths & -0.015 & 0.049 & 0.077 & 0.102 & 0.177 \\
Parking & 0.001 & 0.029 & 0.035 & 0.048 & 0.100 \\
Dist. City Centre & -0.000 & -0.000 & -0.000 & -0.000 & 0.000 \\
Dist. Coast & -0.000 & -0.000 & -0.000 & -0.000 & 0.000 \\
Dist. B1_4 & -0.000 & -0.000 & -0.000 & -0.000 & 0.000 \\
Dist. Swim Place & -0.000 & -0.000 & -0.000 & -0.000 & 0.000 \\
Dist. In123 & -0.000 & -0.000 & -0.000 & -0.000 & 0.000 \\
Rail20_400 & -0.487 & -0.026 & 0.036 & 0.121 & 1.081 \\
Rail24_800 & -0.485 & -0.006 & 0.042 & 0.100 & 1.293 \\
Rail28_1600 & -0.591 & -0.022 & 0.004 & 0.027 & 0.529 \\
CrmRate & -2.750 & -0.291 & -0.093 & 0.042 & 2.479 \\
MedFamInc & 0.000 & 0.000 & 0.000 & 0.000 & 0.000 \\
Main100 & -0.107 & -0.045 & -0.022 & -0.005 & 0.051 \\
RailLi100 & -0.173 & -0.098 & -0.047 & 0.016 & 2.366 \\
\hline \hline
\end{tabular}

Figure 2 visualises the Airbnb Density parameter estimates throughout Sydney. The volatility of coefficient estimates may be related to bandwidth selection issues, due to the application of a single bandwidth for all variables. This is a known limitation of the GWR method, that could be potentially overcome in future work by applying a MGWR (Yu et al., 2020). It must also be noted that the magnitude of coefficient estimates may not be directly comparable across Sydney areas, due to significant differences in underlying Airbnb densities. Nevertheless, examining the direction of Airbnb density coefficients can provide valuable insights about the geographical variation of Airbnb's relationship with property prices throughout Sydney.

Spatial clustering of positive coefficient estimates is evident towards Manly and along the northern beaches, where there is substantial Airbnb activity. This may be expected, given the conceptual 
framework of Airbnb reducing the supply of long-term rentals and in turn increasing housing prices. There is also a significant collection of positive coefficients, ranging up to 0.146 , towards the western centre of Paramatta. The emergence of Paramatta as Sydney's second CBD over the last decade may explain business motivated Airbnb usage in these areas (Guttentag et al., 2017). In these areas, where housing prices are lower and the tourist market is less developed, an increase in Airbnb may be seen as a positive sign for homeowners in signalling growth and greater potential rental revenue. Furthermore, Pawson \& Martin (2020) documented an increasing prominence of 'investor landlords' in Western Sydney, for whom Airbnb presents a direct opportunity to increase rental yield. While Airbnb density here compared to the more touristy central and coastal areas is lower and the impact on housing prices will therefore be less, this nonetheless demonstrates that Airbnb can affect housing prices outside of traditional tourist hotspots.

Figure 2. Spatial distribution of GWR parameter estimates for Airbnb density variable with 190 nearest neighbours

a) Sydney

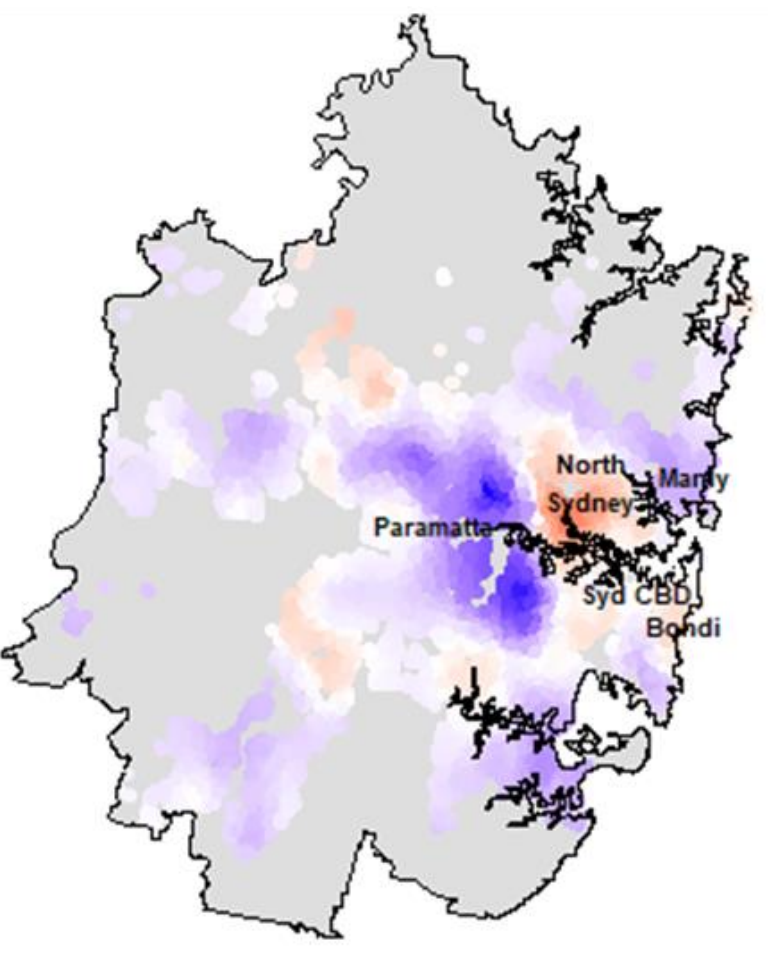

b) Zoom into inner Sydney

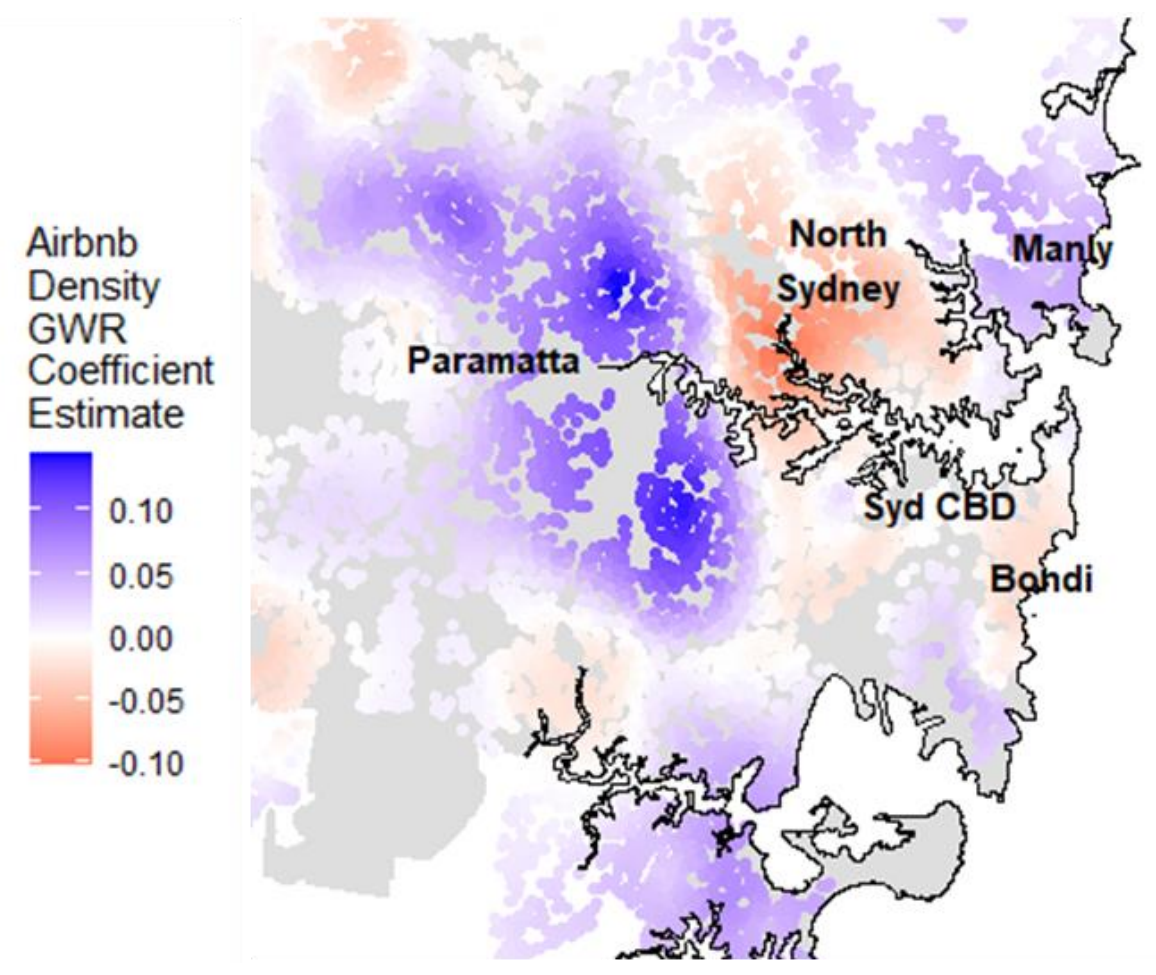

Surprisingly, towards Sydney's more traditional tourist areas of the CBD and eastern suburbs, the Airbnb density coefficients are insignificant or negative. The insignificant coefficients in the city centre may be explained by the significant pre-existing hotel and holiday rentals in these areas, meaning the entrance of Airbnb has not disrupted the housing market as significantly as non-traditional tourist areas. The negative coefficients evident in the eastern suburbs and lower north shore raise the question of whether in high-price areas, there exists a peak threshold of Airbnb activity, whereafter the over saturation of the tourist market is seen as a detractor for local residents. In these cases, negative externalities associated with Airbnb activity such as noise, congestion, and access to amenities for locals, may outweigh the increased rental revenue potential for homeowners (Cocola-Grant, 2016). Notably, it has been shown in Sydney that high- and low-end housing submarkets follow different pricing mechanisms (Bangura \& Lee, 2020a; 2020b). As such, it is not surprising to document a dissimilarity effect of Airbnb activities on housing prices, highlighting the importance of a disaggregated study in gauging the effect of Airbnb. 
It must be noted that upon applying this rational, we might expect Manly and the northern beaches to also experience negative Airbnb coefficients. While this demonstrates the potential limitation of GWR in identifying specific Airbnb property market hot/cold spots, it serves to highlight the spatial complexity of the Airbnb effect across the city. Subsequently, one may assume that Airbnb's impact on affordability is also uneven due to heterogeneous effects. This is an important consideration in the context of affordability policies and highlights the needs for policymakers to consider local tourist and housing market conditions when creating Airbnb regulations.

Future work could examine the variable impacts of Airbnb using case studies of housing submarkets within a city, as well as the temporal evolution of the Airbnb effect over the last decade. Ultimately, through accounting for spatial variation in modelling, our results demonstrate that the relationship between Airbnb and housing prices is complex and varies significantly across and within cities such as Sydney.

\section{Conclusions}

The rapid expansion of home-sharing platforms, such as Airbnb, that has been borderless and largely unregulated has led many to question what their effect on local communities and housing has been. In large tourist cities such as Sydney, where the growth of Airbnb has coincided with rising rental and housing prices, its relationship to the housing market has been a subject of considerable attention for both academics and government regulators. However, as policymakers and local government have begun to apply a range of regulatory measures in response to these concerns, the lack of quality empirical evidence to gauge the causal impact of platforms such as Airbnb on housing prices has become evident.

This study examines empirically the extent to which Airbnb impacts housing prices in Sydney for the first time. Several stages of OLS modelling were performed to control for external shocks and address potential collinearity concerns. The OLS modelling was performed from a residential property valuation perspective, including property characteristics, mobility variables and proximity to amenity measures for the first time in an Airbnb housing market study. Our results indicate that a $1 \%$ increase in Airbnb density is associated with a $2.01 \%$ increase in property prices. This corroborates existing research on the overall impact of Airbnb on the housing market.

Despite this, the existence of housing submarkets and documented spatial unevenness of Airbnb activity throughout Sydney imply that a global model will be insufficient in accounting for the spatial nuances of Airbnb's property market impact. Therefore, a GWR model was developed to explore the spatial variation of the Airbnb effect for the first time. The median Airbnb density parameter of 0.0124 affirms the finding that Airbnb has a predominantly positive influence. However, the Airbnb density coefficient varies from positive in parts of Sydney's west and northern beaches, to insignificant in the $\mathrm{CBD}$, and negative in parts of Sydney's north and eastern suburbs. Through the implementation of a spatially explicit model, our results challenge pre-existing notions of a comprehensively positive relationship between Airbnb and property prices. These results indicate that Airbnb's influence is spatially nuanced and must be considered relative to the tourist and housing markets of local areas.

The findings have several profound implications for policy makers and researchers. Firstly, the finding of a positive association between housing prices and Airbnb density contributes to the ongoing debate of whether policy makers should further regulate and reform the role of home sharing platforms such as Airbnb in Sydney where housing is relatively unaffordable. Despite the potential for home sharing platforms to enhance the efficiency of housing usage, they may also amplify the deterioration of housing affordability. This issue is significant, due to deterioration of housing affordability in Sydney in recent years. Further, the finding of a varied Airbnb effect highlights the need for researchers to incorporate a spatial component in modelling to understand the differential impact of Airbnb on individual housing submarkets. Whereas previous studies have assumed that Airbnb has a homogenous 
impact on housing prices, accounting for spatial components in modelling evidences a more nuanced Airbnb effect. In the context of affordable housing policies, this underscores the need for policymakers to consider individual Airbnb and housing market conditions, rather than resorting to 'one-size-fits-all' approaches. Ultimately, the findings of this study are expected to contribute to a more informed and evidence-based debate on the appropriate level and design of regulation for home-sharing platforms through understanding their impact on housing markets.

\section{Data Availability Statement}

\begin{tabular}{|c|c|c|}
\hline Source & Availability of data & Data availability statement \\
\hline AirDNA & $\begin{array}{l}\text { Data subject to third party } \\
\text { restrictions. }\end{array}$ & $\begin{array}{l}\text { The data that support the findings of this } \\
\text { study are available from AirDNA. } \\
\text { Restrictions apply to the availability of } \\
\text { these data, which were used under license } \\
\text { for this study. Data are available from } \\
\text { https://www.airdna.co/ with the permission } \\
\text { of AirDNA. }\end{array}$ \\
\hline $\begin{array}{l}\text { Australian Property } \\
\text { Monitors (APM) }\end{array}$ & $\begin{array}{l}\text { Data subject to third party } \\
\text { restrictions. }\end{array}$ & $\begin{array}{l}\text { The data that support the findings of this } \\
\text { study are available from } A P M \text {. Restrictions } \\
\text { apply to the availability of these data, } \\
\text { which were used under license for this } \\
\text { study. Data are available from } \\
\text { https://www.apm.com.au/ with the } \\
\text { permission of } A P M \text {. }\end{array}$ \\
\hline Open Street Map & $\begin{array}{l}\text { Data derived from public } \\
\text { domain resources. }\end{array}$ & $\begin{array}{l}\text { The data that support the findings of this } \\
\text { study are available in OpenStreetMap at } \\
\text { https://www.openstreetmap.org/\#map=4/- } \\
\text { 28.15/133.28. }\end{array}$ \\
\hline Google Trends & $\begin{array}{l}\text { Data derived from public } \\
\text { domain resources. }\end{array}$ & $\begin{array}{l}\text { The data that support the findings of this } \\
\text { study are available in Google Trends at } \\
\text { https://trends.google.com/trends/?geo=AU. }\end{array}$ \\
\hline
\end{tabular}

\section{Acknowledgements}

The authors disclose receipt of the following financial support for the research and authorship of this article: This work has been supported by FrontierSI, a not-for-profit company that exists to deliver major benefits to governments, industry and the community in Australia and New Zealand through the application of spatial information. This research was funded through the Cooperative Research Centre Project - Value Australia. 


\section{Appendices}

Appendix A. Summary of OLS modelling results from previous studies

\begin{tabular}{|c|c|c|c|c|}
\hline Author (Year) & City/Region & Observations & Methodology & Results \\
\hline $\begin{array}{l}\text { Horn \& } \\
\text { Merante (2017) }\end{array}$ & Boston & 113,409 & $\begin{array}{l}\text { Traditional } \\
\text { Hedonic (OLS) }\end{array}$ & $\begin{array}{l}\text { One SD increase in } \\
\text { Airbnb listings } \\
\Leftrightarrow 0.4 \% \text { increase in } \\
\text { asking rents }\end{array}$ \\
\hline $\begin{array}{l}\text { Barron et al. } \\
(2020)\end{array}$ & U.S-Wide & 572,858 & $\begin{array}{l}\text { IV using Hotels \& } \\
\text { Restaurants at } \\
\text { fixed point in } \\
\text { time for 'share' } \\
\text { component }\end{array}$ & $\begin{array}{l}1 \% \text { increase in Airbnb } \\
\text { listings } \\
\Leftrightarrow 0.018 \% \text { increase in } \\
\text { rents, } 0.026 \% \text { increase } \\
\text { in house prices }\end{array}$ \\
\hline $\begin{array}{l}\text { Garcia-Lopez } \\
\text { (2020) }\end{array}$ & Barcelona & 7,005 & $\begin{array}{l}\text { IV using Tourist } \\
\text { Score at fixed } \\
\text { point in time for } \\
\text { 'share' } \\
\text { component }\end{array}$ & $\begin{array}{l}\text { Average } \\
\text { neighbourhood of } \\
\text { Airbnb activity } \\
\Leftrightarrow 3.7 \% \text { increase in } \\
\text { sale prices }\end{array}$ \\
\hline $\begin{array}{l}\text { Franco \& } \\
\text { Santos (2021) }\end{array}$ & $\begin{array}{l}\text { Porto \& } \\
\text { Lisbon }\end{array}$ & 1,213 & $\begin{array}{l}\text { IV using Airbnb } \\
\text { Density at fixed } \\
\text { point in time for } \\
\text { 'share' } \\
\text { component }\end{array}$ & $\begin{array}{l}1 \% \text { increase in } \\
\text { municipality Airbnb } \\
\text { share } \\
\Leftrightarrow 3.7 \% \text { increase in } \\
\text { house prices }\end{array}$ \\
\hline
\end{tabular}

Appendix B. Variance Inflation Test run on OLS Variables

\begin{tabular}{|l|r|}
\hline Variables & VIF \\
\hline Bedrooms & 3.026 \\
\hline Baths & 1.870 \\
\hline Parking & 1.337 \\
\hline Dist. City Centre & 1.351 \\
\hline Dist. Coast & 1.377 \\
\hline Dist. B1_4 & 1.102 \\
\hline Dist. Swim Place & 1.271 \\
\hline Dist. In123 & 1.355 \\
\hline Rail20_400 & 1.525 \\
\hline Rail24_800 & 1.378 \\
\hline Rail28_1600 & 1.292 \\
\hline CrmRate & 1.047 \\
\hline MedFamInc & 2.014 \\
\hline Main100 & 2.004 \\
\hline RailLi100 & 1.182 \\
\hline Airbnb Density & 1.484 \\
\hline
\end{tabular}

Notes: Variables displaying a Variation Inflation Factor (VIF) of over ' 5 ' considered to demonstrate collinearity. 


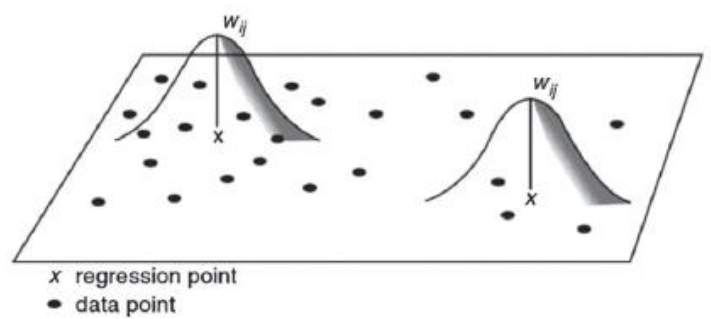

(a) Fixed spatial kernel

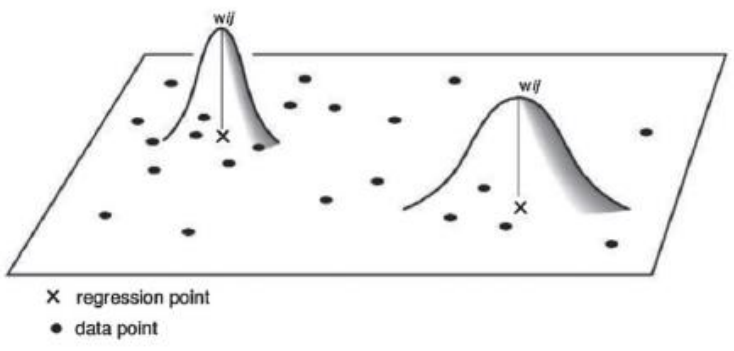

(b) Adaptive spatial kernel

\section{References}

Adamiak, C., Szyda, B., Dubownik, A. \& Garcia-Alvarez, D. (2019) Airbnb Offer in Spain - Spatial Analysis of the Pattern and Determinants of its Distribution. ISPRS Int. J. Geo-Inf., 9(4), 259; doi: https://doi.org/10.3390/ijgi9040259.

Bangura, M. \& Lee, C.L. (2020a) House price diffusion of housing submarkets in Greater Sydney. Housing Studies, 35 (6), pp. 1110-1141. doi: 10.1080/02673037.2019.1648772.

Bangura, M. \& Lee, C.L. (2020b) Housing price bubbles in Greater Sydney: evidence from a submarket analysis. Housing Studies, doi: https://doi.org/10.1080/02673037.2020.1803802.

Barron, K., Kung, E. \& Proserpio, D. (2020) The Effect of Home-Sharing on House Prices and Rents: Evidence from Airbnb. Marketing Science, 40(1), pp. 1-191.

Belniak, S. \& Wieczorek, D. (2017) Property Valuation using Hedonic Price Method - Procedure and its Application. Technical Transactions, 114, pp. 59 - 70.

Boros L, Dudas G and Kovalcsik T (2020), The effects of COVID-19 on Airbnb. Hungarian Geographical Bulletin, 69(4), pp. 363-381, doi: 10.15201/hungeobull.69.4.3.

Brunsdon, C., Fotheringham, A.S. \& Charlton, M.E. (1996) Geographically Weighted Regression: A Method for Exploring Spatial Nonstationarity. Geographical Analysis, 28(4), 281-98.

Buckle C and Phibbs P (2021), Challenging the Discourse around the Impacts of Airbnb through Suburbs Not Cities: Lessons from Australia and COVID-19. Critical Housing Analysis, 8(1), pp. 141-149, doi: 10.13060/23362839.2021.8.1.530.

Cocola-Gant, A. (2016) Holiday Rentals: The New Gentrification Battlefront. Sociological Research Online 21(3): 1-10.

Cox, W. \& Pavletich, H. (2020) 16th Annual Demographia International Housing Affordability Survey: 2020. Performance Urban Planning.

Crommelin, L., Troy, L., Martin, C. \& Parkinson, S. (2018a) Technological disruption in private housing markets: the case of Airbnb. AHURI Final Report 305, Australian Housing and Urban Research Institute Limited, Melbourne.

Crommelin, L., Troy, L., Martin, C. \& Pettit, C. (2018b) Is Airbnb a sharing economy superstar? Evidence from five global cities. Urban Policy and Research. 1-16. doi: 10.1080/08111146.2018.1460722.

Daley, J. \& Coates, B. (2018) Housing Affordability Re-imagining the Australian Dream. Grattan Institute, Report No. 2018-04.

DiPasquale, D. \& Wheaton, W.C. (1992) The Markets for Real Estate Assets and Space: A Conceptual Framework. Journal of the American Real Estate and Urban Economics Association, 20 (1), pp. 181-197. 
Fotheringham, A.S., Brunsdon, C. \& Charlton M. (2003) Geographically Weighted Regression: The Analysis of Spatially Varying Relationships. New York: John Wiley \& Sons.

Franco, S.F. \& Santos, C.D. (2021) The impact of Airbnb on residential property values and rents: Evidence from Portugal. Regional Science and Urban Economics, 88, 103667.

Garcia-Lopez, M.A., Jofre-Monseny, J., Martinez-Mazza, R. \& Segu, M. (2020) Do short-term rental platforms affect housing markets? Evidence from Airbnb in Barcelona. Journal of Housing Economics, 119(C).

Garden, F.L. \& Jalaludin, B.B. (2009) Impact of Urban Sprawl on Overweight, Obesity, and Physical Activity in Sydney, Australia. J Urban Health, 86(1), pp. 19-30.

Grisdale, S. (2019) Displacement by disruption: short-term rentals and the political economy of "belonging anywhere" in Toronto. Urban Geography. doi: 10.1080/02723638.2019.1642714.

Gurran, N. \& Phibbs, P. (2017) When Tourists Move in: How Should Urban Planners Respond to Airbnb? Journal of the American Planning Association, 83(1), pp. 80-92.

Gurran, N., Maalsen, S. \& Shrestha, P. (2020) Is informal housing an affordability solution for expensive cities? Evidence from Sydney, Australia. International Journal of Housing Policy.

Guttentag, D., Smith, S., Potwarka, L. \& Havitz, M. (2017) Why Tourists Choose Airbnb: A Motivation-Based Segmentation Study. Journal of Travel Research 57.

Horn, K. \& Merante, M. (2017) Is home sharing driving up rents? Evidence from Airbnb in Boston. Journal of Housing Economics, 38, pp. 14-24.

Lee, D. (2016) How Airbnb Short-Term Rentals Exacerbate Los Angeles's Affordable Housing Crisis: Analysis and Policy Recommendations. Harvard Law and Policy Review, 10(1), pp. 229- 253.

Lieske SN, van den Nouwelant R, Han H and Pettit JT (2019), A novel hedonic price modelling approach for estimating the impact of transportation infrastructure on property prices. Urban Studies, 58(1), pp. 182202, doi:10.1177/0042098019879382

Manganelli, B., Pontrandolfi, P., Azzato, A. \& Murgante, B. (2014) Using geographically weighted regression for housing market segmentation. International Journal of Business Intelligence and Data Mining, 9(2), pp. 161-177.

Muller, M.P. (2014) An Economic Analysis of Online Sharing Systems' Implications on Social Welfare. In: Proceedings of the European Conference on Information Systems (ECIS) 2014, Tel Aviv, Israel, June 9 11, 2014 ISBN 978-0-9915567-0-0 http://aisel.aisnet.org/ecis2014/proceedings/track10/14.

Nieuwland, S. \& Van Melik, R. (2020), Regulating Airbnb: how cities deal with perceived negative externalities of short-term rentals. Current Issues in Tourism, 23(7), pp. 811-825. doi: 10.1080/13683500.2018.1504899.

Pawson, H. \& Martin, C. (2020) Rental property investment in disadvantaged areas: the means and motivations of Western Sydney's new landlords. Housing Studies, doi: 10.1080/02673037.2019.1709806.

Randolph, B. \& Tice, A. (2013) Who Lives in Higher Density Housing? A Study of Spatially Discontinuous Housing Sub-markets in Sydney and Melbourne. Urban Studies. 50(13), pp. 2661-2681. DOI:10.1177/0042098013477701.

Rayaprolu HS and Levinson D (2019), What's access worth? A hedonic price approach to valuing cities. University of Sydney Working Paper, uri: https://hdl.handle.net/2123/21352.

Saaman, R. (2015) Airbnb, rising rent, and the housing crisis in Los Angeles. LAANE.

Shabrina, Z., Buyuklieva, B. \& NG, M.K.M. (2020) Short-Term Rental Platform in the Urban Tourism Context: A Geographically Weighted Regression (GWR) and a Multiscale GWR (MGWR) Approaches. Geographical Analysis, 0, pp. 1-22.

Shabrina, Z., Arcaute, E. \& Batty, M. (2021) Airbnb and its potential impact on the London housing market. Urban Studies, January 2021. 
Suarez-Vega, R. \& Hernandez JM (2020), Selecting Price Determinants and Including Spatial Effects in Peerto-Peer Accomodation. ISPRS Int. J. Geo-Inf., 9(4), 259, doi: https://doi.org/10.3390/ijgi9040259.

Thackway, W.T. \& Pettit, C.P. (2021) Airbnb during COVID-19 and What This Tells Us about Airbnb's Impact on Rental Prices. Findings, June 2021. doi: https://doi.org/10.32866/001c.23720.

Tu, Q., de Haan, J. \& Boelhouwer, P. (2017) The mismatch between conventional house price modeling and regulated markets: insights from The Netherlands. J Hous and the Built Environ, 32, pp. 599-619. doi: https://doi.org/10.1007/s10901-016-9529-y.

Wachsmuth, D. \& Weisler, A. (2018) Airbnb and the rent gap: Gentrification through the sharing economy. Environment and Planning A: Economy and Space, 50 (6), pp. 1147-1170.

Wen, H., Xiao, Y. \& Hui, E.C.M. (2019) Quantile effect of educational facilities on housing price: Do homebuyers of higher-priced housing pay more for educational resources? Cities, 90 (July 2019), pp. 100112.

Yang, L., Chau, K.W. \& Wang, X. (2019) Are low-end housing purchasers more willing to pay for access to basic public services? Evidence from China. Research in Transportation Economics, 76 (September 2019), 100734. doi: https://doi.org/10.1016/j.retrec.2019.06.001.

Yu, H., Fotheringham, A.S., Li, Z., Oshan, T., Kang, W. \& Wolf, L.J. (2020) Inference in Multiscale Geographically Weighted Regression. Geographical Analysis, 52(1), pp. 87-106.

Zervas, G., Davide, P. \& Byers, J.W. (2017) The Rise of the Sharing Economy: Estimating the Impact of Airbnb on the Hotel Industry. Journal of Marketing Research, 2017, 54 (5), 687-705.

Zhang, S., Wang, L. \& Lu, F. (2019) Exploring Housing Rent by Mixed Geographically Weighted Regression: A Case Study in Nanjing. International Journal of Geo-Information, 8(10), pp. 431. 